\title{
NOTE
}

\section{Effect of Arginine and Arginine-Glucose Infusion on Serum Human Chorionic Gonadotropin Response in Postpartum Women}

\author{
Hiroshi KATO, Yuichi KIDO AND TADASHI TORIGOE \\ Department of Obstetrics and Gynecology, Yamaguchi University School \\ of Medicine, Ube
}

\begin{abstract}
Synopsis
The metabolic patterns of HCG in response to $5 \%$ glucose, arginine-saline and arginine-glucose infusion were investigated in normal postpartum women. Serum HCG concentration was measured by a double antibody radioimmunoassay method. Following arginine-glucose infusion, serum HCG level declined significantly within $30 \mathrm{~min}$ of the infusion, while $5 \%$ glucose or arginine-saline infusion failed to produce any change in HCG concentration. Changes of blood glucose concentration during arginine-glucose infusion was similar to that during $5 \%$ glucose infusion. The possible reasons for the decline of serum HCG level after arginine-glucose infusion are discussed in this paper.
\end{abstract}

Arginine-monochloride has been reported as stimulating release of growth hormone and immunoreactive insulin (Parker et al., 1967; Knopf et al., 1965). However, to our knowledge, no reports have been made on the effects of arginine infusion on gonadotropin, especially on human chorionic gonadotropin (HCG) response. The purpose of this study is to determine the response of serum $\mathrm{HCG}$ level to arginine or glucose infusion in normal postpartum women.

\section{Materials and Methods}

Blood samples were obtained from eighteen normal postpartum patients two or three days after delivery. The subjects were divided into three groups: Group 1 , 6 subjects which received $500 \mathrm{ml}$ of $5 \%$ glucose solution; Group 2, 6 subjects which received arginine in saline solution; Group 3, 6 subjects which received arginine in $5 \%$ glucose solution.

Infusion test: All subjects were tested after an overnight fast. Five hundred $\mathrm{mg} / \mathrm{kg}$ body weight of L-arginine monochloride (Levargin, Taisho Seiyaku Co., Ltd., Tokyo) in saline solution or in $5 \%$ glucose

Received for publication July 6, 1973. solution was infused into the antecubital vein at a constant rate within 40 min period. Blood samples were drawn immediately before the infusion and at $15,30,45,60$ and 90 min intervals after the start of the infusion. No side effects occurred in all cases during and after infusion.

To prove the effect of arginine-glucose solution upon serum HCG level, sera from three pregnant subjects were incubated with arginine-glucose solution. To 1.0 $\mathrm{m} l$ of the serum, $0.05,0.1$ or $0.2 \mathrm{~m} l$ of arginine-glucose solution $(40 \mathrm{mg} / \mathrm{ml}$ in $5 \%$ glucose solution) was added respectively, and the mixtures were incubated for 60 $\min$ at $37^{\circ} \mathrm{C}$.

Serum HCG activity was measured in duplicate by a double antibody radioimmunoassay previously described (Kato, 1970). Anti-HCG serum obtained from guinea pig cross-reacted very weakly with HTSH. Purified HGH, ACTH (porcine), prolactin (porcine) and L-arginine-monochloride had no effects in this assay system. Blood glucose level was determined by a glucose-oxidase method.

\section{Results}

Changes of the serum HCG and blood glucose levels are shown in Figure 1. No significant changes of $\mathrm{HCG}$ levels were noted after $5 \%$ glucose or arginine-saline infusion. 

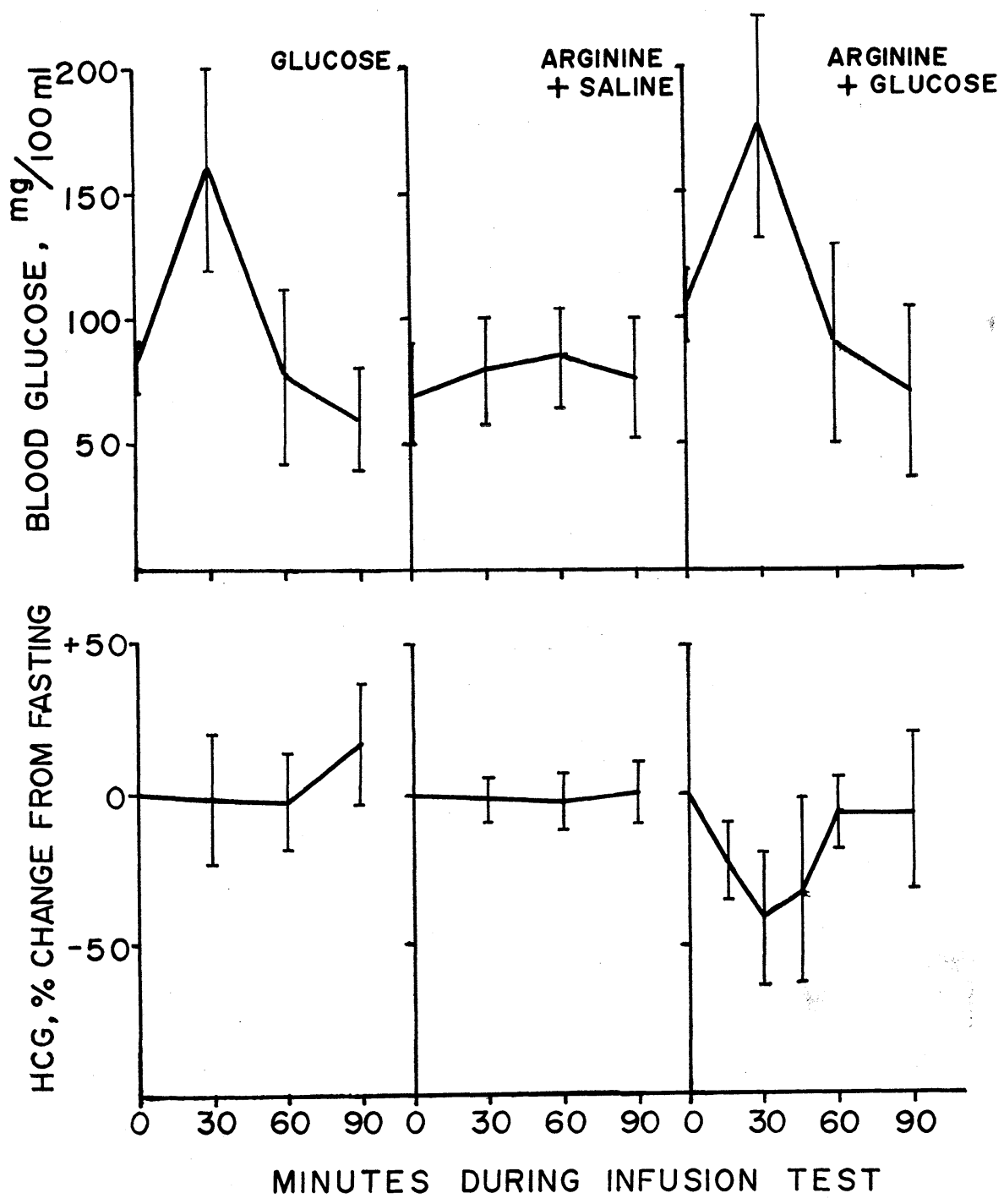

Fig. 1. Mean glucose and HCG levels during $5 \%$ glucose, arginine-saline and arginineglucose infusion in normal postpartum women.

A significant decline in serum HCG levels was observed after arginine-glucose infusion at 30 min of the infusion. The maximal decline was $43 \pm 23 \%$ of the preinfusion level which was statistically significant $(\mathrm{p}<0.05)$. The serum HCG levels returned to the preinfusion level after $60 \mathrm{~min}$. Blood glucose levels after arginine-glucose infusion rose from $100 \pm 20$ $\mathrm{mg} / 100 \mathrm{ml}$ to $176 \pm 48 \mathrm{mg} / 100 \mathrm{ml}$, which was similar to that during $5 \%$ glucose infusion.

Effect of arginine-glucose solution upon serum HCG level in vitro: The results are shown in Table 1. No degradation of immunological activities of HCG were noted after the incubation with arginine-glucose solution. 
Table 1. Effect of arginine-glucose solution on immunological activity of serum HCG in vitro. Each serum was incubated with different amounts of arginine-glucose solution $(40 \mathrm{mg} / \mathrm{m} l$ in $5 \%$ glucose solution).

\begin{tabular}{lllll}
\hline & \multicolumn{4}{c}{ HCG, IU/m $l$} \\
\cline { 2 - 5 } SUBJECT & \multicolumn{4}{c}{ ARGININE-GLUCOSE SOLU- } \\
& \multicolumn{4}{l}{ TION ADDED, $\mu$ l } \\
& 0 & 25 & 125 & 250 \\
\hline K.F. & 26.0 & 26.6 & 22.6 & 25.4 \\
K. U. & 34.0 & 33.2 & 33.2 & 32.0 \\
T. O. & 62.0 & 60.0 & 64.0 & 65.0 \\
\hline
\end{tabular}

\section{Discussion}

Tyson et al. (1969) reported that arginine administration, in saline solution, had failed to change the maternal chorionic somatomammotropin levels during pregnancy. Reitano et al. (1971) showed that, in premature infants, infusion of arginine plus glucose produced higher serum insulin levels than do arginine alone. In our data, the serum HCG levels remained unchanged after arginine-saline infusion or $5 \%$ glucose infusion, whereas following the infusion of arginine-glucose solution a significant decrease in serum HCG levels was noted. The decrease levels of serum HCG may be caused by the combined effect of arginine and glucose.

The explanation for the decline of $\mathrm{HCG}$ levels after arginine-glucose infusion is not known yet. In several cases during the first trimester of pregnancy, the serum HCG declines were also observed after arginineglucose infusion (Kato, unpublished data). Three possible explanations may be suggested: First, the increase of HCG metabolism; Second, inactivation of HCG activity; Finally, suppression of HCG secretion. The metabolic clearance rate of HCG has been discussed by several investigators. Tawfik et al. (1969) reported that following intravenous injection of $\mathrm{HCG}$, the disappearance rate of $\mathrm{HCG}$ in plasma had two exponential components, an initial fast component with a half-life of 5.6 $\mathrm{hr}$ and a second slower component with a half-life of $23.9 \mathrm{hr}$. In this respect, the third hypothesis seems to be an inadequate explanation for the decline of HCG levels, because serum $\mathrm{HCG}$ levels declined about $50 \%$ within $30 \mathrm{~min}$.

To prove the direct effects of arginineglucose solution on the HCG activity, several serum specimens from pregnant subjects were incubated with arginine-glucose solution. No significant changes of immunological activities of HCG were observed. The mechanism of HCG metabolism in vitro is different from that in vivo, and the nature of the rapid decline of serum HCG levels following arginine-glucose infusion remains to be verified. However, the first hypothesis seems to be the possible explanation for this phenomenon.

\section{Acknowledgment}

We are indebted to Dr. M. Horino for his invaluable technical advice.

\section{References}

Knopf, R. F., J. W. Conn, S. S. Fajans, J. C. Floyd, E. M. Guntsche and J. A. Rull (1965). J. Clin. Endocrinol. 25, 1140.

Kato, H. (1970). Nippon Sanka-Fuzinka Gakkai Zassi 22, 1317. (In Japanese)

Parker, M. L., J. M. Hammond and W. H. Daughaday (1967). J. Clin. Endocrinol. 27, 1129.

Reitano, G., S. Grasso, G. Distefano and A. Messina (1971). J. Clin. Endocrinol. 33, 924.

Tyson, J. E., D. Rabinowitz, T. J. Merimee and H. Friesen (1969). Am. J. Obst. \& Gynec. 103, 313.

Tawfik, R., E. Gurpide and R. L. V. Wiele (1969). J. Clin. Endocrinol. 29, 92. 